\title{
A Case of Mycobacterium Simiae Mimicking Malignancy
}

\author{
Morgan, Samantha, De Hoyos and Patricio and Peters Jay* \\ University of Texas Health Science Center, USA
}

Submission: February 27, 2018; Published: March 08, 2018

*Corresponding author: Patricio and Peters Jay, University of Texas Health Science Center, San Antonio and the South Texas Veteran's Health Care System, San Antonio, Texas, USA, Email: PETERS@uthscsa.edu

\section{Introduction}

In 1965, Mycobacterium simiae was first isolated from macaques [1]. Isolation of M. simiae has been mostly confined to the Southern US, Israel, and Cuba but is increasingly reported worldwide [2-3]. In the University Hospital in San Antonio, Texas, M. simiae has become the second most frequently isolated nontuberculous mycobacterium surpassed only by Mycobacterium avium complex. Out of patients analyzed in this facility during an 11 year period, $10 \%$ had definite infection and $76 \%$ were thought to be colonized [4]. M. simiae often colonizes the airway, but clinical disease has been increasingly reported especially in immunocompromised patients and those with an underlying lung disease.

\section{Case Report}

A 56-year-old woman with a prior history of breast cancer presented to clinic with a productive cough, malaise, hoarseness and myalgia. She denied night sweats, weight loss, wheezing, or hemoptysis and indicated that all symptoms resolved on their own except for the productive cough. The patient has a history of invasive carcinoma of the right breast (diagnosed in 2008). A CT scan reported scarring at bilateral apices and lingual as well as tree-in-bud- opacities in the right middle lobe. A transthoracic biopsy of the right middle lung performed prior to chemotherapy initiation showed active granulomatous inflammation and scattered epithelial cells of uncertain significance. A PETCT, showed moderately increased pathologic activity that corresponded to a pleural based soft tissue structure in the area of the right middle lobe. Sputum cultures where negative and the patient proceeded with treatment with adjuvant radiation, bilateral mastectomy and hormonal therapy.

In 2014 the patient had a positive acid-fast bacilli (AFB) sputum sample and was referred to an ID specialist. She was prescribed antibiotics that included clarithromycin and ethambutol however, due to severe reflux the therapy was aborted. Upon a follow up a chest $\mathrm{x}$ ray a nodular opacity at the right lung was observed. A CT scan revealed bronchiectasis in the right upper lobe and lingula, as well as characterized the pulmonary nodule as a measuring $12 \times 10$ sub-solid nodule Sputum samples were sent for AFB and fungal cultures, no growth was reported. The patient had a bronchoscopy performed, with transbronchial biopsies showing no evidence of malignancy or granuloma. A bronchoalveolar lavage was positive for M. simiae, no treatment was initiated at that time. Follow up CT scans where performed every 3 to 6 months. A new solid, spiculated masslike lesion measuring $22 \times 17 \mathrm{~mm}$ and adjacent to the trachea was seen in the right upper lobe. This lesion was not observed on a CT scan performed 4 months before. A PET CT showed a high avidity of this nodule, with an SUV of 10.3 at the right upper lobe nodule (Figure $1 \& 2$ ).

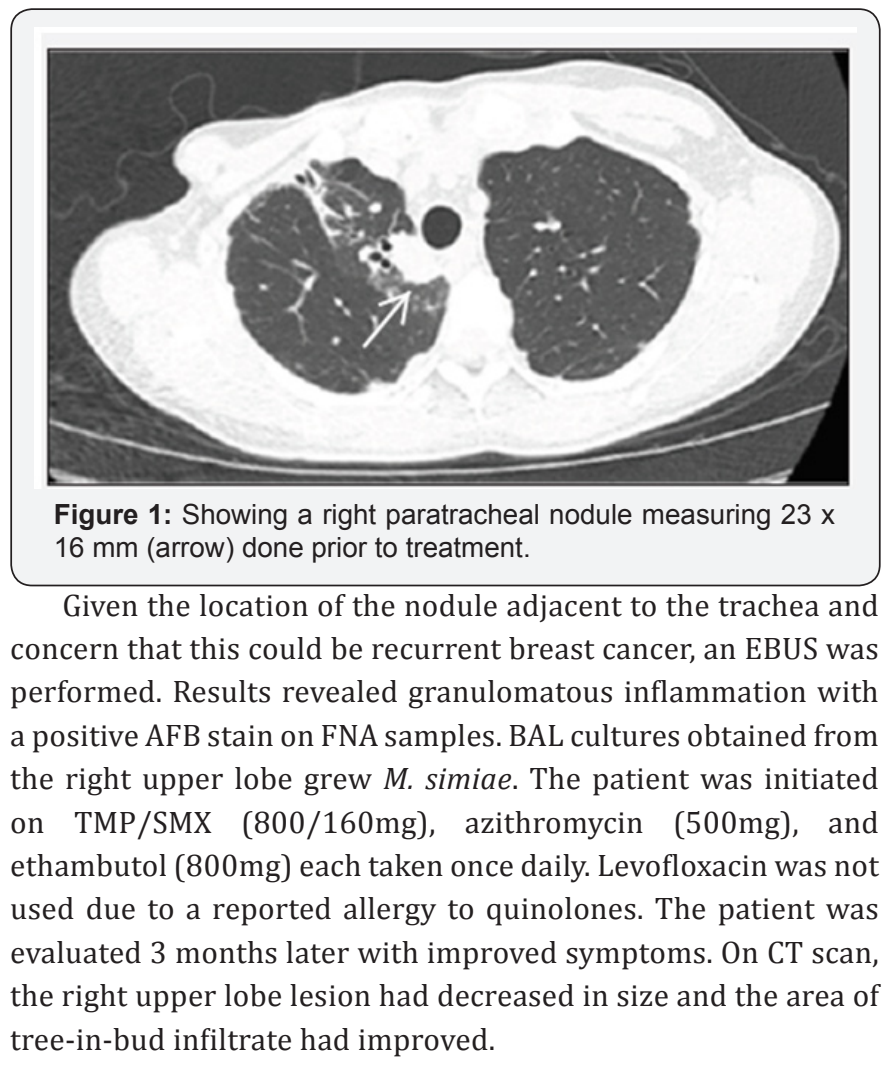




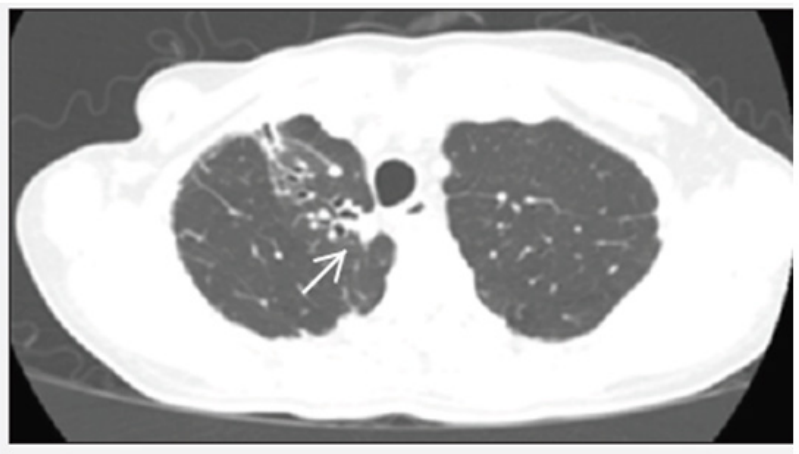

Figure 2: Shows a repeat CT scan 6 months after initiation of treatment with TMP/SMX (800/160 mg), azithromycin (500 mg), and ethambutol $(800 \mathrm{mg}$ ), nodule measuring $11 \times 10 \mathrm{~mm}$ (arrow point).

\section{Discussion}

The uniqueness of this case is the presentation of M. simiae infection and its development into a hypermetabolic nodule with rapid growth. An early report by Bell and coworkers found M. Simiae was a frequent colonizer of sputum but rarely cause disease [5]. However, a more recent report from our institution, suggested that the organism was pathogenic in up to $20 \%$ of patients if both definite and probable diagnosis were considered. In study between 1999-2006 from the Netherlands, Van Ingen et al. [6] described $M$. simiae isolated from patients with abnormal chest radiographs. Only $11 \%$ presented as suspected malignant lesions on chest radiography. Data from this cohort show that $M$. simiae isolates where cultured mostly from sputum (44\%) and bronchoalveolar lavage (52\%) samples. However, lung biopsy specimens reported growth in only $4 \%$ of the samples. It is difficult to determine the actual percent of patients with M. simiae disease in this study. However, the American Thoracic Society Guidelines state that in any patient with systemic symptoms, an abnormal chest radiograph, and a positive culture of a nontuberculous mycobacteria (NTM) from BAL fluid could be considered to have active disease [7]. Yet, it is unclear if this standard should be applied to NTM organisms with low pathogenicity. In our case, the FNA performed by EBUS showed granulomatous inflammation and was AFB positive from the patient's pulmonary nodule. However, M. simiae was only grown from the BAL culture. The patient responded well to NTM therapy with resolution of infiltrate and reduction in the size of her pulmonary nodule. This case points out the difficulty of diagnosing M. simiae disease and the diagnostic utility of performing EBUS to obtain additional tissue from pulmonary nodules or lymph nodes.

\section{References}

1. Karassova V, Weissfeiler, E Krasznay (1965) Occurrence of atypical mycobacteria in Macacus rhesus. Acta Microbiol Acad Sci Hung 12(3): 275-282.

2. WN, Krasnow I, Johanson WG (1983) Mycobacterium simiae. Clinical features and follow-up of twenty-four patients. Am Rev Respir Dis 127: 35-38.

3. Conger NG, O'Connell RJ, Laurel VL, Olivier KN, Graviss EA, et al. (2004) Mycobacterium simiae outbreak associated with a hospital water supply. Infect Control Hosp Epidemiol 25(12): 1050-1055.

4. Valero G, Peters J, Jorgensen JH, Graybill JR (1995) Clinical isolates of Mycobacterium simiae in San Antonio, Texas. An 11-yr review. Am J Respir Crit Care Med 152(5 Pt 1): 1555-15557.

5. Bell RC, Higuchi JH, Donavan WN, Johanson WG (1983) Mycobacterium simiae clinical features and follow up of twenty-four patients. Am Rev Respir Dis 127(1): 35-38.

6. Van Ingen J, Boeree MJ, Dekhuijzen PNR, van Soolingen D (2007) Clinical relevance of mycobacterium simiae in pulmonary samples. Eur Respir J 31(1): 106-109.

7. Griffith D, Aksamit T, Brown-Elliot B, Catanzaro A, Daley C, et al. (2007) An official ATS/IDSA Statement: Diagnosis, Treatment, and Prevention of Nontuberculous Mycobacterial Diseases. Amer Tho Soc 175(4): 367416.

Your next submission with Juniper Publishers will reach you the below assets

- Quality Editorial service

- Swift Peer Review

- Reprints availability

- E-prints Service

- Manuscript Podcast for convenient understanding

- Global attainment for your research

- Manuscript accessibility in different formats (Pdf, E-pub, Full Text, Audio)

- Unceasing customer service

Track the below URL for one-step submission https://juniperpublishers.com/online-submission.php 